\title{
STUDI TIME SERIES HIDRO OSEANOGRAFI UNTUK PENGEMBANGAN PELABUHAN PANJANG
}

\author{
Dian Pratiwi ${ }^{1}$ \\ Dosen Teknik Sipil, Fakultas Teknik dan Ilmu Komputer, Universitas Teknokrat Indonesia ${ }^{1}$ \\ (dian.pratiwi@teknokrat.ac.id)
}

\begin{tabular}{lll}
\hline Received: (14 Mei 2020) & Accepted: (27 Juni 2020) & Published : (30 Juli 2020) \\
\hline
\end{tabular}

\begin{abstract}
Climate change is happening in Indonesia led to rising sea levels, changes in temperature, air humidity and erosion in coastal areas. In terms of Oceanography climate change caused the increase in wave height, tidal range and changing patterns of wind speed. With the data recorded of the wind on Airport that closest with the sea to the time series of high wave the sea and wind pattern changes can be predicted.

The study was conducted to determine how much change the pattern of winds and high waves that occur between the ranges of 1989-1993 and 1998-2011 in the Bay of Lampung. With the data recording was made of a rose wind roses wind and waves to describe the suitability of the wave pattern of roses and wind roses. Besides recording wind data used to predict wave height and period that occurs due to the existence of a certain wind patterns and forecasting of extreme waves with a certain re-kala.

Based on the result showed that the pattern of changes in wind speed in the range of 4-6 knots, which fell between the years 1989-1993 and 2007-2011. This suggests a change in air pressure caused by temperature changes dipermukanaan temperature of the earth. Temperature results in perbeadaan air pressure, air pressure patterns change mengakibatakan wind speed, and wind changes cause changes in wave height in the Bay of Lampung. Thus it can be seen the effects of changes in the timeframe 1989-2011 climate.
\end{abstract}

Keywords: Wind roses, roses wave, Forecasting Extreme Waves, Wave Height and Period.

\begin{abstract}
Abstrak
Perubahan iklim yang terjadi di Indonesia menyebabkan kenaikan muka air laut, perubahan temperatur, kelembaban udara dan erosi di wilayah pesisir pantai. Dari segi Oseanografi perubahan iklim menyebabkan terjadinya kenaikan tinggi gelombang, pasang surut air laut dan perubahan pola kecepatan angin. Dengan data pencatatan angin pada Bandar Udara terdekat dengan laut secara time series maka tinggi gelombag laut dan perubahan pola angin dapat diramalkan.
\end{abstract}

Penelitian ini dilakukan untuk mengetahui seberapa besar perubahan pola angin dan tinggi gelombang yang terjadi antara rentang tahun 1989-1993 dan 1998-2011 di wilayah Teluk Lampung. Dengan adanya data pencatatan angin dibuatlah suatu mawar angin dan mawar gelombang untuk mendeskripsikan kesesuaian pola dari mawar gelombang dan mawar angin. Selain itu pencatatan data angin digunakan untuk meramalkan tinggi dan periode gelombang yang yang terjadi akibat adanya suatu pola angin tertentu dan peramalan gelombang ekstrim dengan kala ulang tertentu.

Berdasarkan hasil penelitian didapatkan pola perubahan kecepatan angin yaitu pada rentang 4-6 knot yang mengalami penurunan antara tahun 1989-1993 dan 2007-2011. Hal ini menunjukkan adanya perubahan tekanan udara yang diakibatkan oleh perubahan temperatur suhu dipermukanaan bumi. Temperatur mengakibatkan adanya perbeadaan tekanan udara, tekanan udara mengakibatakan perubahan pola kecepatan angin, dan perubahan angin menimbulkan perubahan ketinggian gelombang pada Teluk Lampung. Dengan demikian dapat terlihat adanya efek dari perubahan iklum dalam rentang waktu 19892011.

Kata Kunci: Mawar Angin, Mawar gelombang, Peramalan Gelombang Ekstrim, Tinggi dan Periode Gelombang

To cite this article: Pratiwi. (2020). Studi Time Series Hidro Oseanografi Untuk Pengembangan Pelabuhan Panjang. Journal of Infrastructural in Civil Engineering (JICE) Vol(01), 1-14 


\section{PENDAHULUAN}

Akhir-akhir ini di wilayah Indonesia telah terjadi perubahan iklim (climate change) yang menyebabkan terjadinya kenaikan muka air laut, perubahan temperatur, kelembaban udara dan erosi di wilayah pesisir pantai. Di daerah Teluk Lampung akibat dari perubahan iklim sangat berpengaruh terhadap pengembangan pelabuhan yang dapat ditinjau dari segi hidrologi dan hidro oseanografi. Dari segi hidrologi perubahan iklim mempengaruhi siklus hidrologi yang berdampak pada intrusi air laut dan aliran bawah tanah. Sedangkan hidro oseanografi berpengaruh terutama terhadap pasang surut air laut, gelombang dan angin.

Ketiga aspek dari Hidro Oseanografi yaitu angin, gelombang dan pasang surut saling berkaitan. Angin dapat menimbulkan gelombang dan tekanan angin (wind set up) yang kemudian berpengaruh terhadap tekanan pada kapal dan bangunan pelabuhan. Pasang surut berpengaruh terhadap penentuan elevasi muka air (design water level) pada rancangan bangunan seperti pemecah gelombang, dermaga, pelampung penambat, kedalaman alur pelayaran dan perairan pelabuhan dan sebagainya. Elevasi muka air rencana ditetapkan berdasarkan pengukuran pasang surut dalam periode waktu yang panjang. Gelombang yang menyerang bangunan pantai akan menimbulkan gaya-gaya yang bekerja pada bangunan pantai. Dengan adanya climate change maka akan terjadi suatu pola perubahan angin yang kemudian mempengaruhi gelombang dan pasang surut yang terjadi, sehingga dalam suatu pengembangan pelabuhan ketiga aspek hidro oseanografi tersebut perlu diperhitungkan.

Di wilayah Teluk Lampung, studi tentang hidro oseanografi jarang dilakukan. Pencatatan data angin yang dilakukan hanya merupakan satu-satunya aspek yang digunakan dalam perencanaan bangunan pantai khususnya pelabuhan, sedangkan pencatatan gelombang yang terjadi dalam waktu panjang belum dilakukan. Sehingga peramalan gelombang dilakukan hanya berdasarkan data angin yang terjadi. Selain itu, dengan adanya efek rumah kaca yang mengakibatkan adanya perubahan iklim memungkinkan adanya perubahan pola angin yang kemudian berakibat pada pasang surut, arus dan gelombang yang terjadi. Analisis terhadap data angin dan gelombang dapat membuktikan kesesuaian antara data angin tercatat dengan data gelombang tercatat. Dengan adanya studi ini dapat diketahui efek dari perubahan iklim yang terjadi dengan pengaruh dari pola angin yang terjadi.

Studi tentang hidro oseanografi dapat memberikan informasi tentang akibat dari perubahan iklim yang terjadi melalui pola perubahan angin, arus dan gelombang yang terjadi. Untuk wilayah Teluk Lampung studi ini sangat diperlukan guna pengembangkan wilayah ini terutama dalam hal industri, ekonomi, sarana transportasi, pariwisata dan sebagainya yang kemudian dapat meningkatkan kesehjateraan penduduk sekitar dan pendapatan daerah.

\section{TELAAH PUSTAKA}

1. Data Angin

Dalam suatu peramalan gelombang diperlukan suatu data angin dengan data angin yang diguanakan dalam peramalan gelombang adalah data di permukaan laut pada lokasi pembangkitan. Satu knot adalah panjang satu menit garis bujur melalui khatulistiwa yang ditempuh dalam satu jam atau $1 \mathrm{knot}=1,852 \mathrm{~km} / \mathrm{jam}=$ $0,5 \mathrm{~m} /$ detik. Dengan adanya data pencatatan angin jam-jaman maka dapat diketahui angin dengan kecepatan tertentu dan durasinya, kecepatan angin maksimum, arah angin dan dapat pula dihitung kecepatan rerata angin harian.

2. Konversi Kecepatan Angin

Pengukuran data angin diperlukan untuk peramalan gelombang. Data angin pengukuran dengan kapal perlu dikoreksi dengan menggunakan persamaan berikut (Bambang Triatmodjo, 1999):

$U=2,16 U_{s}{ }^{7 / 9}$

Hubungan antara angin di atas laut dan di daratan diberikan dalam persamaan seperti terdapat dalam grafik dibawah ini : 


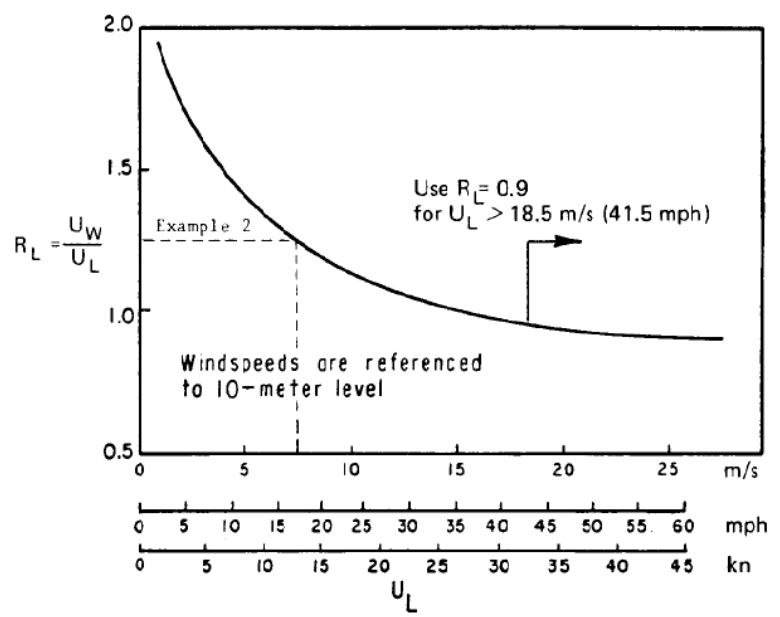

Gambar 2. Hubungan antara kecepatan angin di darat dan di laut.

(Shore Protection Manual 1984 Volume 1)

Rumus-rumus dan grafik-grafik pembangkitan gelombang mengandung variabel $\mathrm{U}_{\mathrm{A}}$, yaitu faktor tegangan angin (wind stress factor) yang dapat dihitung dari kecepatan angin. Kecepatan angin dikonversikan pada faktor tegangan dengan menggunakan rumus sebagai berikut (Bambang Triatmodjo, 1999) :

$U_{A}=0,71 U^{1,23}$

\section{A. Pasang Surut}

Pasang surut adalah fluktuasi muka air laut sebagai fungsi waktu karena adanya gaya tarik benda-benda di langit, terutama matahari dan bulan terhadap massa air laut di bumi (Bambang Triatmodjo, 1999). Selain itu pasang surut dapat didefinisikan sebagai fenomena naik-turunnya muka air laut yang diakibatkan oleh gaya tarik-menarik antara Bumi dengan benda-benda di angkasa terutama Bulan dan Matahari. Walaupun Bulan mempunyai massa yang relatif kecil dibanding Matahari, namun karena letaknya yang relatif dekat dengan Bumi, maka pengaruh Bulan adalah lebih besar dibanding pengaruh Matahari. Kejadian pasangsurut merupakan kejadian yang berosilasi sehingga semakin panjang data yang dikumpulkan akan semakin baik hasil prediksi pasang-surut (Roos, A., 1997 dalam Dwi Jokowinarno, 2007). Meskipun massa bulan jauh lebih kecil dari massa matahari, tetapi karena jaraknya terhadap bumi jauh lebih dekat, maka pengaruh gaya tarik bulan terhadap bumi lebih besar daripada pengaruh gaya tarik matahari.

\section{B. Gelombang}

Gelombang di laut bisa oleh angin (gelombang angin), gaya tarik matahari dan bulan (pasang surut), letusan gunung berapi atau gempa di laut (tsunami), kapal yang bergerak, dan sebagainya.

Bentuk atau besaran gelombang laut tergantung dari empat faktor yaitu :

a. Kecepatan angin (u).

b. Lamanya angin bertiup $\left(\mathrm{T}_{\mathrm{u}}\right)$.

c. Kedalaman laut (d) dan luasnya perairan.

d. Fetch (F), yaitu jarak antara terjadinya angin sampai lokasi gelombang tersebut. (Soedjono,2002).

\section{Peramalan Gelombang}

1. Fetch

Bentuk fetch tidak teratur akibat bentuk garis pantai yang tidak teratur, maka untuk keperluan peramalan gelombang perlu ditentukan besarnya fetch efektif yang dihitung dengan rumus (Bambang Triatmodjo, 1999) :

$F_{\text {eff }}=\frac{\sum\left(x_{i} \times \cos \alpha_{i}\right)}{\sum \cos \alpha_{i}}$ 
2. Peramalan Tinggi Gelombang

Dalam melakukan peramalan tinggi gelombang terlebih dahulu mencari fetch efektif. Setelah mendapatkan nilai fetch efektif maka perhitungan tinggi gelombang diberikan dengan rumus (Bambang Triatmodjo, 1999) :

$\frac{g H_{m 0}}{U_{A}^{2}}=1,6 \times 10^{-3}\left(\frac{g F}{U_{A}^{2}}\right)^{\frac{1}{2}}$

$\frac{g T_{m}}{U_{A}^{2}}=2,875 \times 10^{-1}\left(\frac{g F}{U_{A}^{2}}\right)^{\frac{1}{3}}$

$\frac{g t}{U_{A}^{2}}=68,8\left(\frac{g F}{U_{A}^{2}}\right)^{\frac{2}{3}}$

Untuk panjang fetch tidak terbatas diberikan rumus sebagai berikut (Bambang Triatmodjo, 1999) :

$\frac{g H_{m 0}}{U_{A}^{2}}=2,433 \times 10^{-1}$

$\frac{g T_{m}}{U_{A}^{2}}=8,133$

$\frac{g t}{U_{A}^{2}}=7,17 \times 10^{-4}$

3. Peramalan Gelombang Dengan Periode Ulang Tertentu

Frekuensi gelombang-gelombang besar merupakan faktor yang mempengaruhi perencanaan bangunan pantai. Untuk menetapkan gelombang dengan periode ulang tertentu dibutuhkan data gelombang dalam jangka waktu pengukuran cukup panjang. Data tersebut bisa berupa data pengukuran gelombang atau data gelombang hasil prediksi berdasarkan data angin (Bambang Triatmodjo, 1999). Metode ini dihitung dengan rumus.

a. Metode Weibull

$P\left(H_{s} \leq H_{s m}\right)=1-\frac{m-0,2-\frac{0,27}{\sqrt{K}}}{N_{T}+0,2+\frac{0,23}{\sqrt{K}}}$

b. Metode Fisher Pippet Tipe 1

$P\left(H_{s} \leq H_{s m}\right)=1-\frac{m-0,44}{N_{T}+0,12}$

a. $\quad$ Metode Weibull

$y_{m}=\left[-\ln \left\{-\ln F\left(H_{s} \leq H_{s m}\right)\right\}\right]^{\frac{1}{K}}$

b. Metode Fisher Pippet Tipe 1

$y_{m}=-\ln \left\{-\ln F\left(H_{s} \leq H_{s m}\right)\right\}$

\section{METODE PENELITIAN}

Bagan alir penelitian dari penelitian ini ditunjukkan pada gambar dengan penjelasan sebagai berikut :

1. Pengumpulan data sekunder berupa data angin terukur tahun 1989-1993 dan 2001-2005 dari Stasiun BMKG Branti dan data gelombang terukur pada Teluk Lampung selama 5 tahun (1989-1993).

2. Data angin selama 5 tahun (1989-1993) dikelompokkan menjadi data angin bulanan dan tahunan, kemudian dengan data angin tersebut dibuat suatu diagram mawar angin bulanan dan tahunan dengan menggunakan software WRPLOT dan dengan cara manual.

3. Data gelombang terukur selama 5 tahun (1989-1993) dikelompokkan menjadi data bulanan dan data tahunan, kemudian dibuat suatu mawar gelombang dengan menggunakan software WRPLOT dan dengan cara manual. 


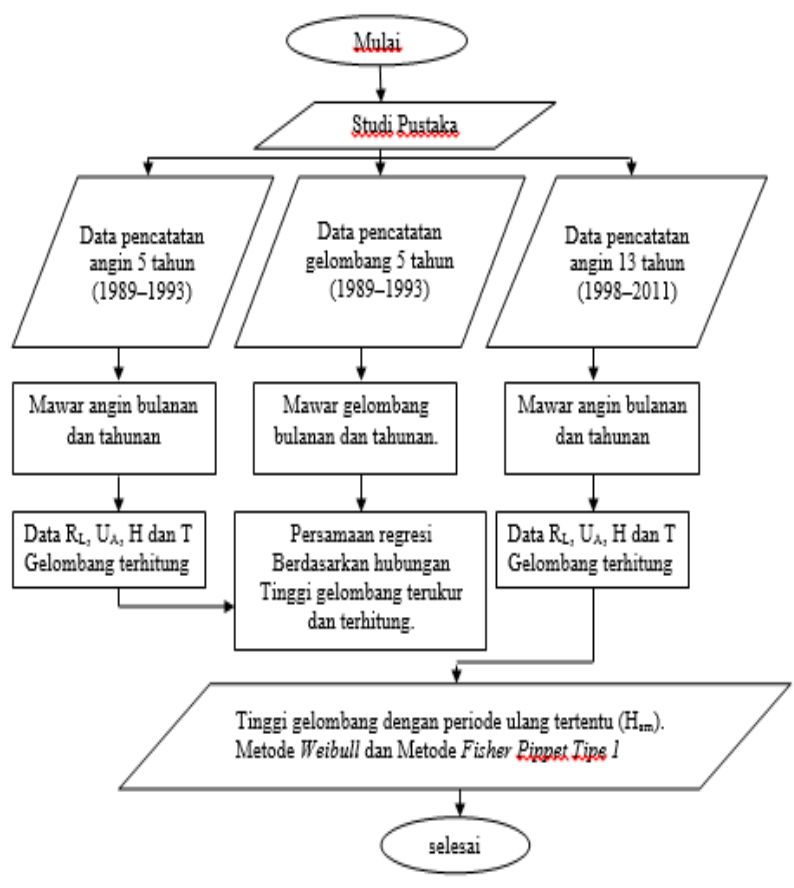

4. Membandingkan kesesuaian antara mawar gelombang terukur dan mawar angin terukur.

5. Dengan data angin terukur dibuat suatu peramalan gelombang dengan menentukan fetch efektif yang ada di Teluk Lampung, durasi angin rata - rata yang terukur setiap 6 (enam) jam sekali. Kemudian mencari nilai kecepatan angin dilaut $\left(\mathrm{R}_{\mathrm{L}}\right)$, setelah itu mencari faktor tegangan angin $\left(\mathrm{U}_{\mathrm{A}}\right)$, kemudian, setelah kedua nilai tersebut didapatkan maka tinggi dan periode gelombang dapat dicari. Perhitungan ini dilakukakn sesuai dengan pencatatan angin yang terjadi selama 5 (lima) tahun.

6. Membandingkan antara gelombang terukur dan gelombang terhitung.

7. Dengan menggunakan data pencatatan angin selama 13 (tiga belas) tahun dimulai tahun 1998 hingga 2011 dibuat suatu mawar angin yang kemudian dibuat suatu peramalan tinggi gelombang.

8. Data gelombang selama 13 tahun (1998-2011) dibuat suatu peramalan gelombang dengan menggunakan metode Weibull dan Metode Fisher Pippet Tipe 1. Kedua metode ini dilakukan untuk memperkirakan tinggi gelombang signifikan dengan berbagai periode ulang.

\section{HASIL DAN PEMBAHASAN}

Analisis data yang dilakukan meliputi beberapa macam analisis, antara lain: [1] analisis data angin menjadi mawar angin, [2] analisis data gelombang terhitung dengan menggunakan data angin, [3] analisis data gelombang terukur menjadi mawar gelombang, dan [4] analisis peramalan tinggi gelombang ekstrim gelombang dengan metode Fisher Pippet Type I dan Weibull.

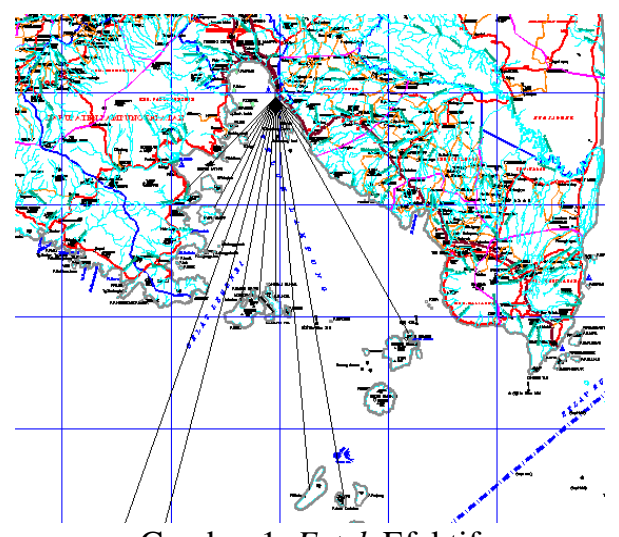

Gambar 1. Fetch Efektif 
Berdasarkan Gambar 1. dicari nilai fetch efektif berdasarkan atas jarak yang terukur dari lokasi penelitian atau titik observasi keujung akhir fetch dengan deviasi pada kedua sisi menggunakan pertambahan $5^{0}$ sampai sudut sebesar $45^{\circ}$ pada kedua sisi dari arah angin yaitu arah selatan.

$F_{\text {eff }}=\frac{\sum\left(x_{i} \times \cos \alpha_{i}\right)}{\sum \cos \alpha_{i}}=\frac{392,67}{411,98}=20,705 \mathrm{~km}$

Perhitungan peramalan tinggi gelombang batas dilakukan untuk mencari batas tinggi gelombang yang dihasilkan dengan kecepatan angin tertentu sesuai dengan skala Beaford.

Tabel 1. Hasil Perhitungan Batas Tinggi Gelombang

\begin{tabular}{llcc}
\hline No. & \multicolumn{1}{c}{ Sifat Angin } & $\begin{array}{c}\text { V } \\
(\mathrm{knot})\end{array}$ & $\begin{array}{c}\text { Height } \\
(\mathrm{m})\end{array}$ \\
\hline 1 & Calm & $0-1$ & $0-0,054089$ \\
2 & Angin Sepoi & $1-3$ & $0,05409-0,177263$ \\
3 & Angin Sangat Lemah & $4-6$ & $0,2349-0,344$ \\
4 & Angin Lemah & $7-10$ & $0,3988-0,5561$ \\
5 & Angin Sedang & $11-16$ & $0,6078-0,829$ \\
6 & Angin Agak Kuat & $17-21$ & $0,874-1,048$ \\
7 & Angin Kuat & $22-27$ & $1,097-1,312$ \\
8 & Angin Kencang & $28-33$ & $1,355-1,494$ \\
9 & Angin Sangat Kuat & $34-40$ & $1,550-1,893$ \\
10 & Badai & $41-47$ & $1,951-2,308$ \\
11 & Badai Kuat & $48-55$ & $2,3685-2,8003$ \\
12 & Angin Ribut & $56-63$ & $2,8630-3,3094$ \\
13 & Angin Topan & $>63$ & $>3,3741$ \\
\hline
\end{tabular}

Berdasarkan arah dan kecepatan angin selama 5 tahun didapatkan arah dominan yaitu pada arah North East (tenggara) sedangkan arah dominan mawar gelombang berada pada arah North (Utara). Ketidaksesuaian antara arah dominan dari mawar angin dan mawar gelombang dikarenakan adanya perbedaan lokasi antara data gelombang terukur yang berada pada $7,5^{\circ} \mathrm{LU}$ dan $103,5^{\circ} \mathrm{BT}$. Sedangkan lokasi data pengukuran angin berada pada stasiun Branti yang berada pada $5,14^{0} \mathrm{LU}$ dan $105,11^{0} \mathrm{BT}$. Dengan jarak antara stasiun BMKG Branti dan Lokasi Pengukuran berada pada jarak $99 \mathrm{~km}$.

A. Analisis Data Angin Bulanan dan Tahunan 1989-1993, Data Angin Bulanan dan Tahunan 1998-2011, dan Data Gelombang Bulanan dan Tahunan 1989-1993.

1. Analisa Data Angin Bulanan dan Tahunan 1989-1993

Analisis data angin bulanan dilakukan untuk melihat kesesuaian antara data angin dari tahun ketahun. Berdasarkan skala Beaford kecepatan angin diklasifikasikan berdasarkan sifat hembusan angin. Dengan pengklasifikasian kecepatan angin berdasarkan persentase kecepatan dominan yang terjadi maka efek dari perubahan iklim dapat diketahui. 


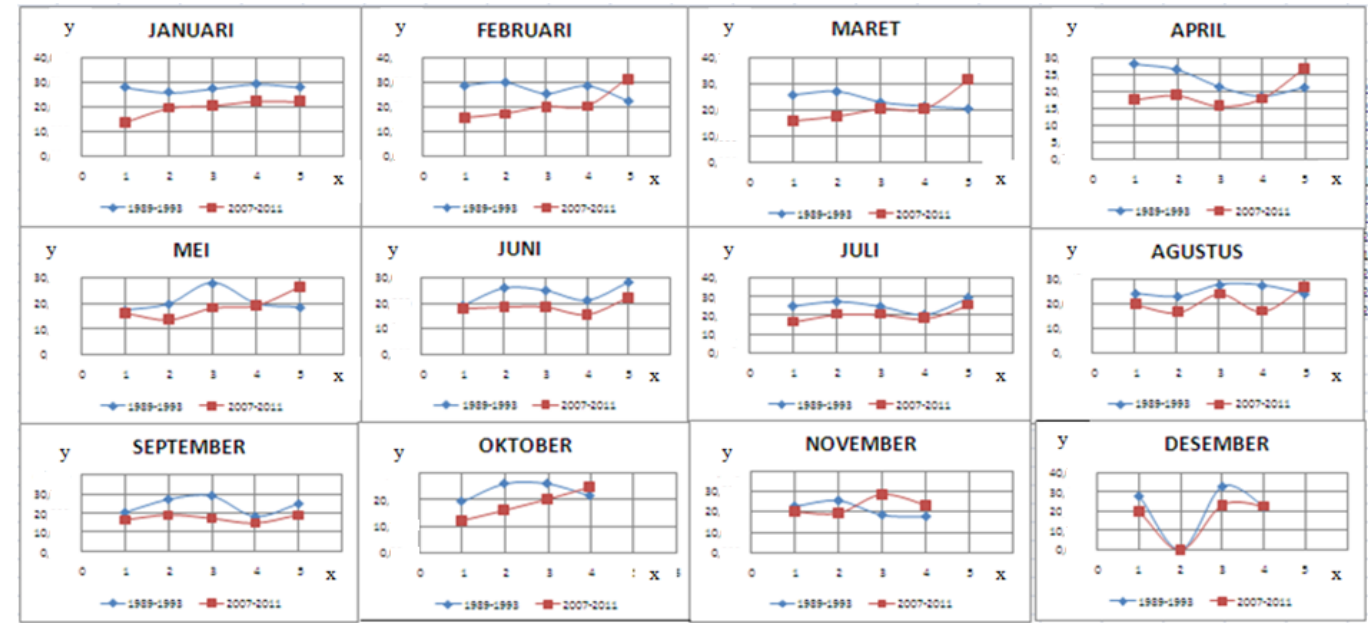

Keterangan :

$\mathrm{y} \quad=$ persentase jumlah distribusi kecepatan 4-6 knot

$\mathrm{x} \quad=$ tahun ke- kejadian

Gambar 2. Gafik Hubungan Kecepatan 1989-1993 dan 2007-2011 Dengan Rentang Kecepatan 4-6 Knot

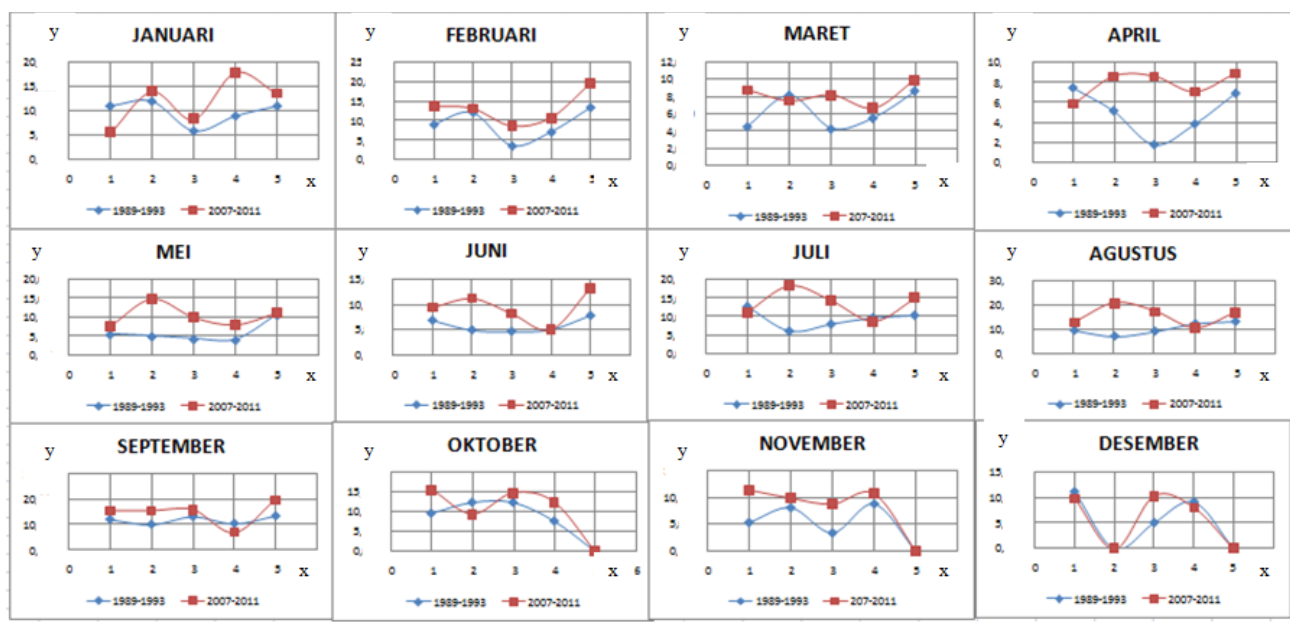

Keterangan :

$\mathrm{y} \quad=$ persentase jumlah distribusi kecepatan 7-10 knot

$\mathrm{x}=$ tahun ke- kejadian

Gambar 3. Gafik Hubungan Kecepatan 1989-1993 dan 2007-2011 Dengan Rentang Kecepatan 7-10 Knot 


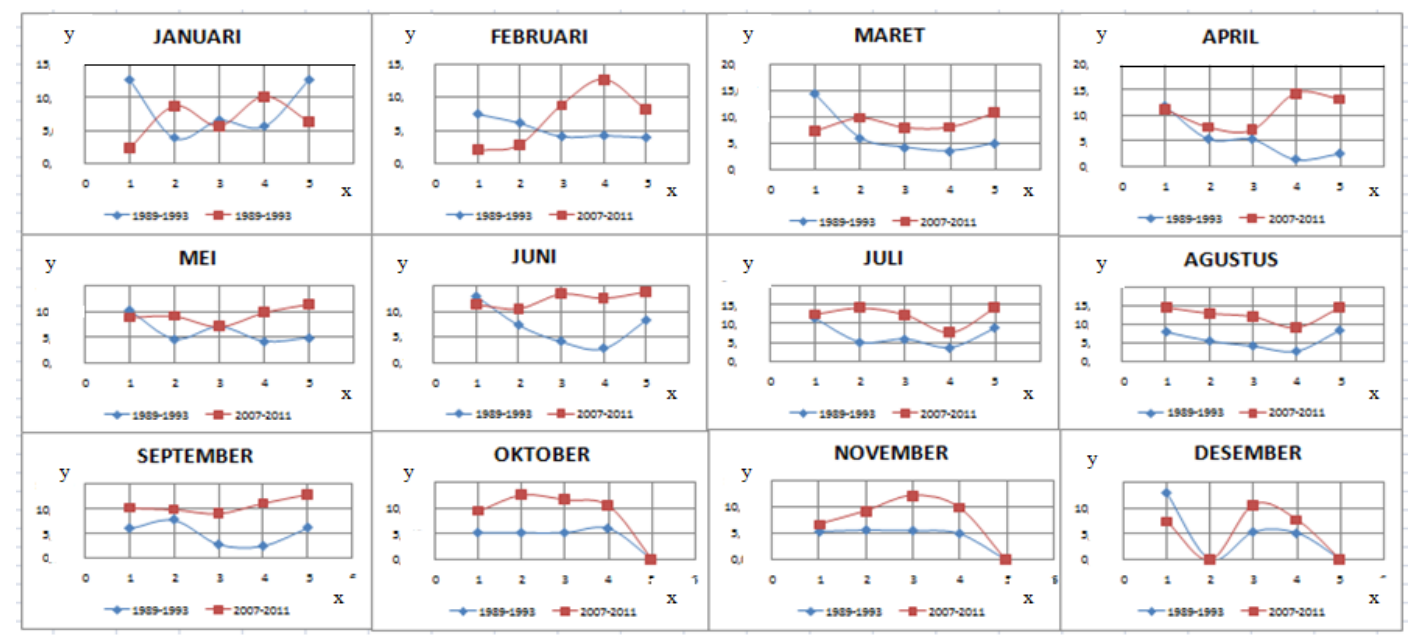

Keterangan :

$\mathrm{y} \quad=$ persentase jumlah distribusi kecepatan 1-3 knot

$\mathrm{x} \quad=$ tahun ke- kejadian

Gambar 4. Gafik Hubungan Kecepatan 1989-1993 dan 2007-2011 Dengan Rentang Kecepatan 1-3 Knot

Berdasarkan grafik di atas diketahui pada kecepatan 4-6 knot, tahun 1989-1993 mempunyai jumlah distribusi jumlah kecepatan yang lebih besar dibandingkan dengan tahun 2007-2011. Sedangkan pada rentang kecepatan 1-3 knot dan 7-10 knot, tahun 1989-1993 mempunyai distribusi kecepatan yang lebih kecil dibandingkan dengan tahun 2007-2011. Hal itu menunjukkan adanya perubahan distribusi kecepatan angin. Dengan asumsi bahwa angin berhembus dari tekanan udara yang tinggi menuju tekanan udara yang rendah dan perbedaan kecepatan angin yang dipengaruhi oleh kelandaian perbedaan tekanan udara dan tekanan udara disebabkan oleh adanya perbedaan suhu udara yang terjadi. Dengan asumsi tersebut dapat dilihat adanya perbedaan suhu yang drastis antara tahun 1989-1993 dan 2007-2011. Dengan kondisi seperti yang terjadi pada grafik di atas maka terdapat efek dari perubahan iklim tau climate change dalam rentang tahun tersebut.

2. Analisis Data Gelombang Terukur Bulanan dan Tahunan 1989-1993

Berdasarkan hasil pengukuran gelombang signifikan 1989-1993, dicari tiga nilai hasil pengukuran gelombang teratas pertahun selama 5 tahun. Dengan hasil pengukuran seperti terlihat pada tabel berikut ini.

Tabel 2. Hasil Perhitungan Tiga Nilai Gelombang Maksimum 1989-1993

\begin{tabular}{cccccc}
\hline Tahun & 1989 & 1990 & 1991 & 1992 & 1993 \\
\hline \multirow{2}{*}{ Gelombang } & 2,37 & 3 & 3,14 & 2,96 & 2,76 \\
Terukur & 2,21 & 2,7 & 2,6 & 2,94 & 2,48 \\
& 2,18 & 2,56 & 2,56 & 2,86 & 2,46 \\
Rata-Rata & 2,253 & 2,753 & 2,767 & 2,920 & 2,567 \\
\hline
\end{tabular}

Dengan merata-ratakan ketiga hasil gelombang rata-rata pertahun, didapatkan hasil sebesar 2,652 meter. Dengan parameter 2,652, diambil suatu rentang gelombang berdasarkan perhitungan konversi data angin menjadi data gelombang yaitu 2,3685-2,8003 meter. Sehingga didapatkan persentase tinggi gelombang yang terjadi pada ketinggian 2,3685-2,8003 meter pertahunnya selama 5 tahun. 


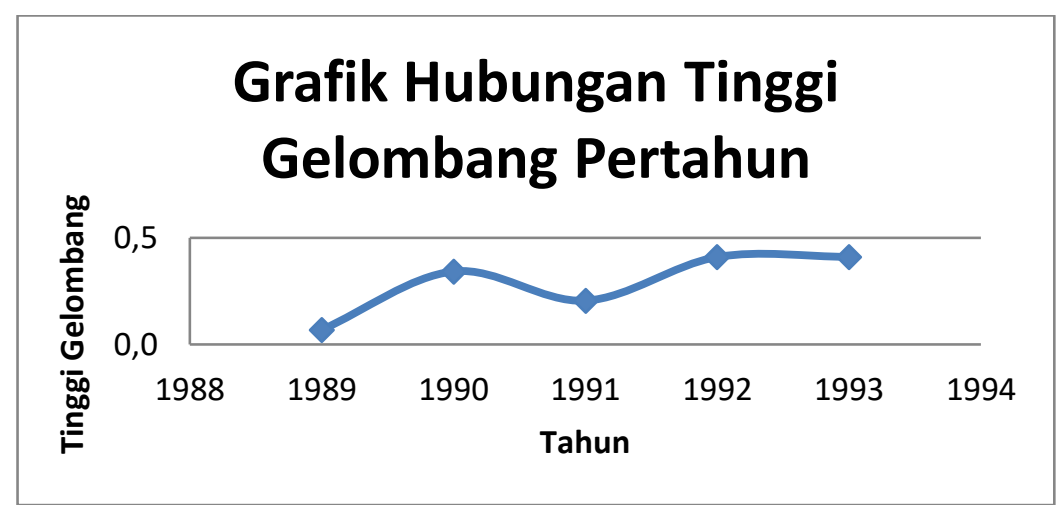

Gambar 5. Grafik Hubungan Tinggi Gelombang Signifikan Pertahun

Grafik di atas menunjukkan perubahan yang terjadi pada tinggi gelombang signifikan 1989-1993. Perbedaan tersebut terjadi karena adanya perubahan kecepatan angin dari tahun ketahun. Jika tinggi gelombang meningkat maka kecepatan angin meningkat. Peningkatan kecepatan angin diakibatkan oleh peningkatan perbedaan tekanan pada dua lokasi yang berbeda. Dengan demikian dapat terlihat adanya perubahan iklim yang terjadi pada rentang tahun 1989-1993.

B. Analisis Terhadap Data Gelombang Terukur dan Data Gelombang Terhitung Berdasarkan Data Pencatatan Angin di Stasiun Badan Meteorologi, Klimatologi dan Geofisika (BMKG) Branti (19891993).

Berdasarkan hasil pencatatan tinggi gelombang yang dilakukan selama 5 tahun (1989-1993) menghasilkan grafik hubungan antara waktu pencatatan gelombang dan tinggi gelombang yang dalam hal ini tinggi gelombang yang diamati hanya tinggi gelombang yang diakibatkan oleh angin (Significant Height Of Wind Waves). Grafik tersebut dapat terlihat pada gambar di bawah ini.

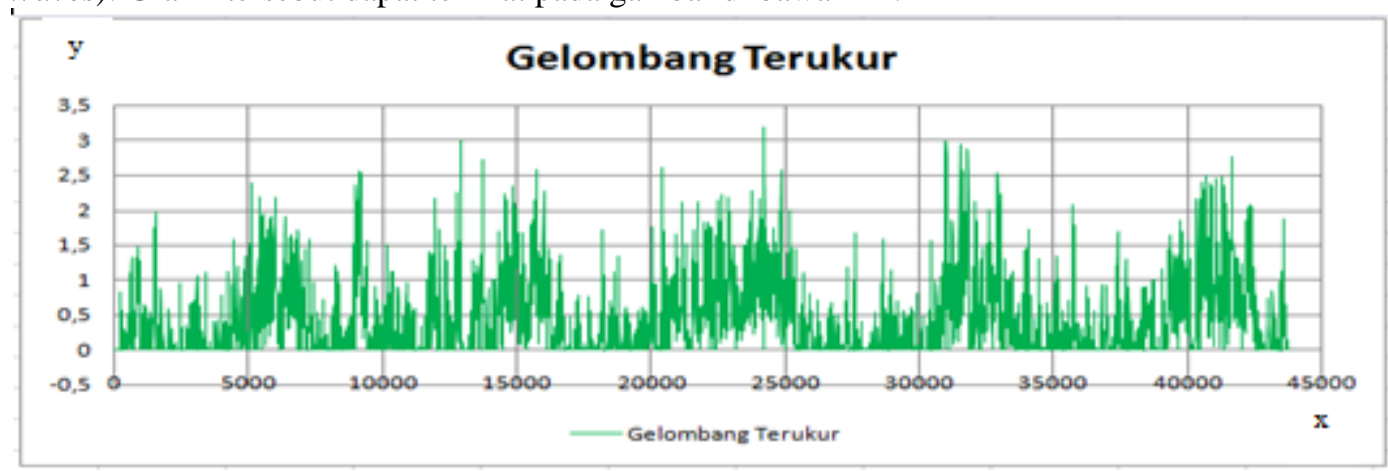

Keterangan :

$\mathrm{y}=$ tinggi gelombang terhitung $(\mathrm{m})$

$\mathrm{x}=$ waktu pencatatan tiap $6 \mathrm{jam}$

Gambar 6. Grafik Gelombang Terukur Pada $103,5^{\circ}$ BT dan $7,5^{0} \mathrm{LU}$

Nilai rata-rata gelombang yang terjadi sebesar $0,425 \mathrm{~m}$. Gelombang maksimum yang terjadi pada pengukuran adalah $3,14 \mathrm{~m}$. Hasil ini tidak jauh berbeda dengan hasil gelombang terhitung dengan menggunakan data pencatatan angin pada stasiun BMKG Branti, yang terlihat pada gambar 14. Nilai ratarata gelombang terhitung rata-rata yang terjadi pada gambar tersebut adalah 0,15 meter, sedangkan gelombang perhitungan maksimum yang terjadi adalah 4,09 $\mathrm{m}$. 


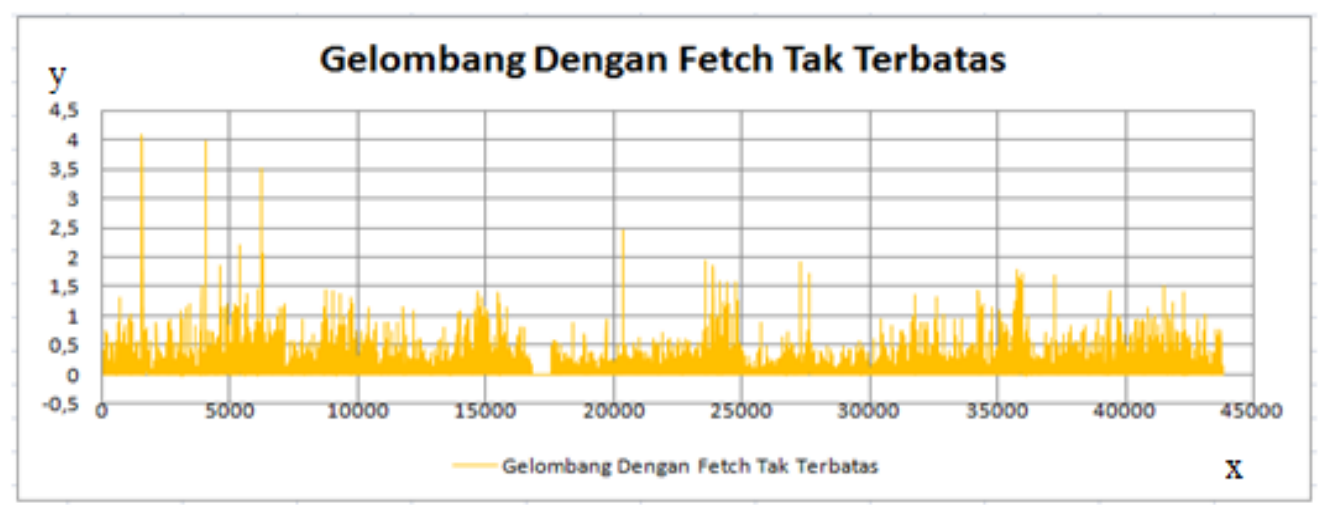

Keterangan :

$\mathrm{y}=$ tinggi gelombang terhitung $(\mathrm{m})$

$\mathrm{x}=$ waktu pencatatan tiap 6 jam

Gambar 7. Grafik Gelombang Terhitung dengan Fetch Tak terhingga

Pada titik lokasi pengukuran gelombang, peramalan gelombang juga dilakukan pada pelabuhan Panjang. Hasil yang didapatkan unuk gelombang pada titik lokasi Pelabuhan Panjang memberikan hasil yang tidak berbeda jauh dengan gelmbang terhitung dan tercatat pada lokasi pengukuran gelombang, yaitu pada titik $7,5^{\circ} \mathrm{LS}$ dan $103,5^{\circ} \mathrm{BT}$. Nilai rata-rata gelombang yang terjadi adalah $0,12 \mathrm{~m}$ dan ketinggian gelombang maksimum yang dicapai adalah 3,05 meter.

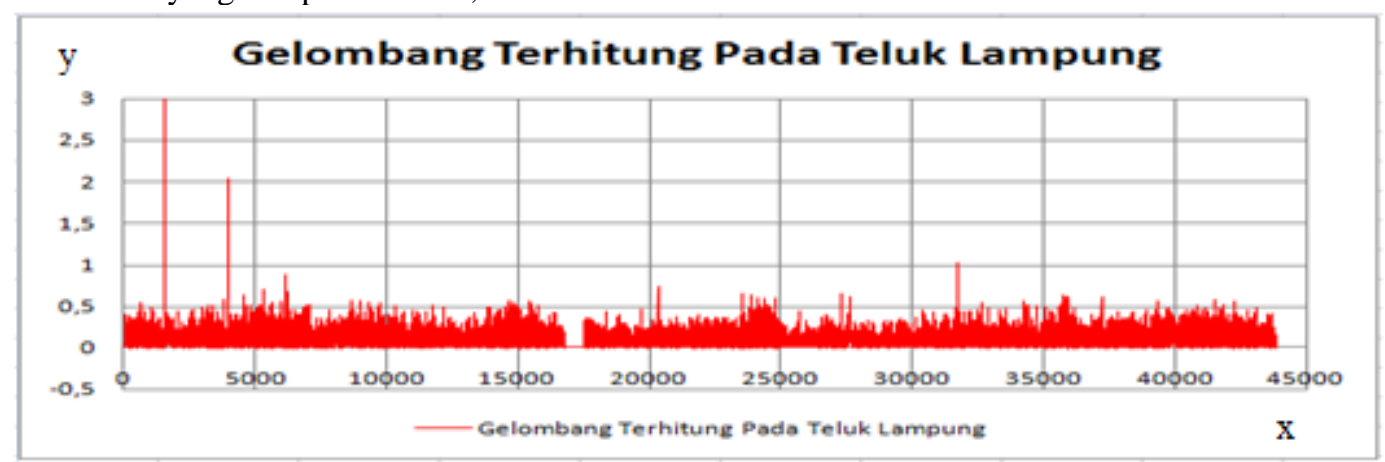

Keterangan :

$\mathrm{y}=$ tinggi gelombang terhitung $(\mathrm{m})$

$\mathrm{x}=$ waktu pencatatan tiap $6 \mathrm{jam}$

Gambar 8. Grafik Gelombang Terhitung Pada Pelabuhan Panjang

Dari ketiga pengukuran dibuat suatu grafik hubungan antara waktu pengukuran ke-yang diberikan dengan simbol x dan tinggi gelombang dengan simbol y didapatkan suatu grafik seperti gambar di bawah ini.

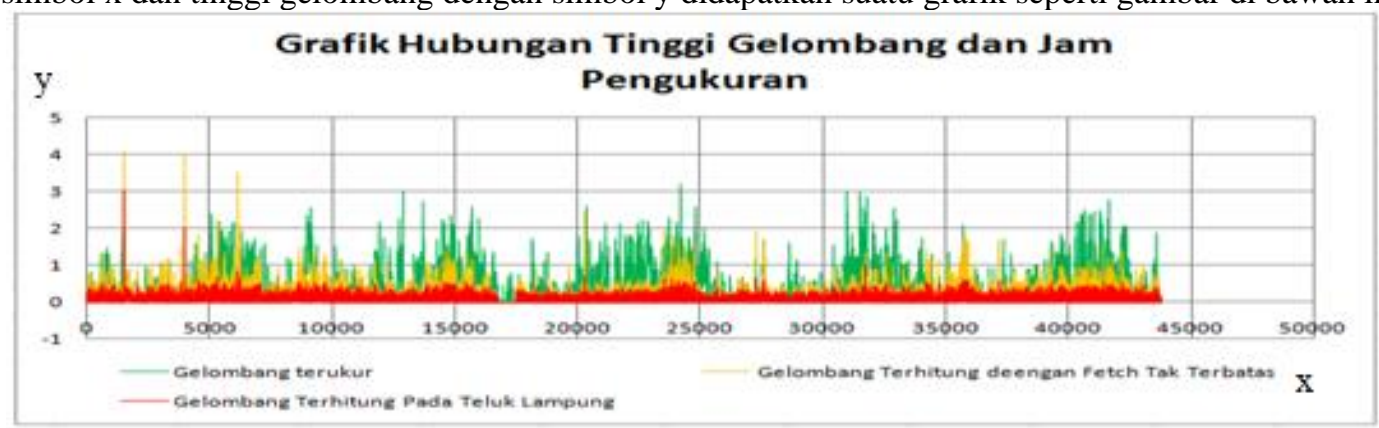

Keterangan :

$\mathrm{y}=$ tinggi gelombang terhitung $(\mathrm{m})$

$\mathrm{x}=$ waktu pencatatan tiap $6 \mathrm{jam}$

Gambar 9. Grafik Hubungan Tinggi Gelombang dan Jam pengukuran 
Pada grafik di atas terdapat perbedaan yang terjadi antara gelombang yang terukur dan terhitung. Hal ini dikarenakan terdapat rumus empirik dalam penentuan nilai $\mathrm{R}_{\mathrm{L}}$ yang ( Gambar 2.) dilakukan pada lokasi yang berbeda, yaitu pada Danau Great Lake, Amerika Serikat.

Dari grafik di atas dapat tinggi gelombang yang didapatkan dari hasil pengukuran pada lokasi $7,5^{\circ} \mathrm{LS}$ dan $103,5^{\circ} \mathrm{BT}$ ataupun pada pengukuran di Pelabuhan Panjang Teluk Lampung.

\section{Analisis Data Angin Tercatat (1998-2011)}

1. Mawar Angin pada pengukuran 1998-2011

Dari hasil pencatatan angin selama rentang tahun 1998-2011 dibuat suatu tabel mawar angin yang menggambarkan arah dan kecepatan angin dominan yang terjadi pada rentang tahun tersebut. Selain itu pembuatan mawar angin digunakan sebagai tahap pengklasifikasian berdasarkan arah angin dan rentang kecepatan yang terjadi.

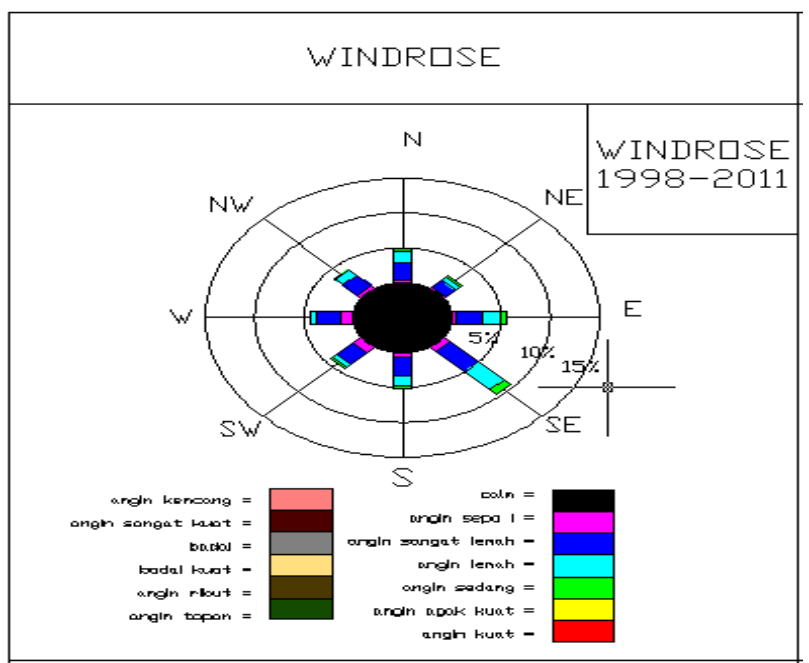

Gambar 10. Mawar Angin 1998-2011

Berdasarkan Gambar. didapatkan arah dominan angin yang terjadi yaitu terletak pada arah Tenggara (North East) dan kecepatan dominan yang terjadi terletak pada 4-6 knot. Pengukuran ini sesuai dengan pengukuran angin yang dilakukan pada tahun 1989-1993 dimana arah dan kecepatan dominan yang terjadi adalah sama. Hal itu menunjukkan bahwa tidak ada perubahan arah angin yang cukup besar antara rentang tahun tersebut.

2. Peramalan Tinggi Gelombang 1998-2011

Peramalan terhadap tinggi gelombang bertujuan untuk memperkirakan gelombang yang terjadi akibat adanya angin yang berhembus disekitar lokasi penelitian ataupun di lokasi yang dekat dengan titik lokasi penelitian. Berikut ini disajikan grafik hasil dari peramalan tinggi dan periode Gelombang di Pelabuhan Panjang.

Peramalan gelombang tertinggi terjadi pada ketingian 3,76 m. Dengan parameter ini, peramalan gelombang ekstrim dengan kala ulang tertentu dapat dilakukan. 


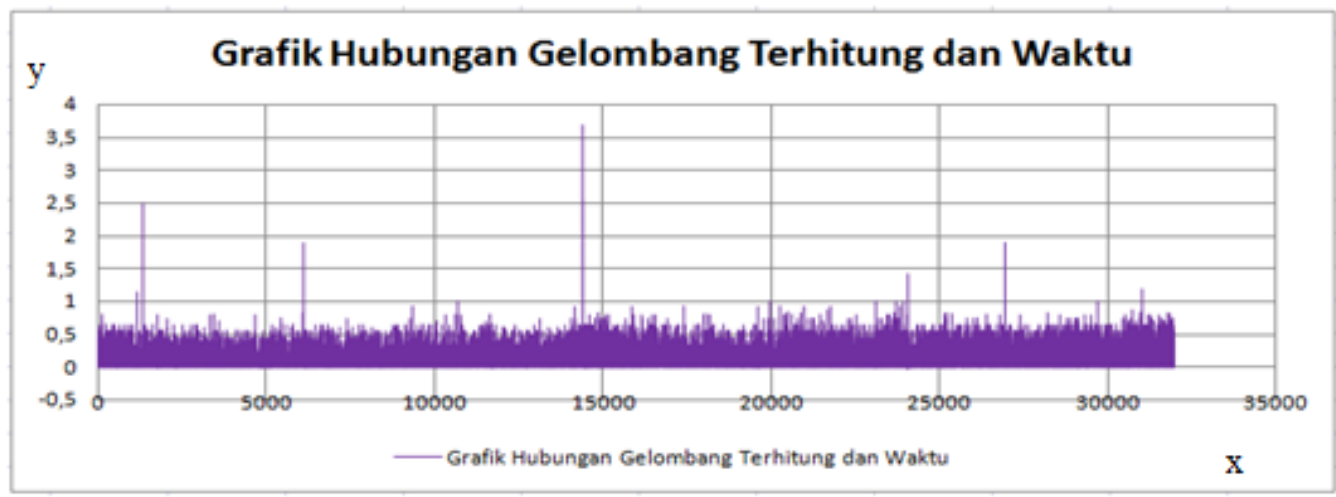

Keterangan :

$\mathrm{y}=$ tinggi gelombang terhitung $(\mathrm{m})$

$\mathrm{x}=$ waktu pencatatan tiap 6 jam

Gambar 11. Grafik Hubungan Waktu dan Tinggi Gelombang Terukur Selama Empat Tahun (1998-2001)

3. Peramalan Tinggi Gelombang Ekstrim dengan Metode Weibull dan Fisher Pippet Type I

Peramalan gelombang ekstrim dilakukan untuk mencari gelombang tertinggi yang terjadi dengan kala ulang tertentu.

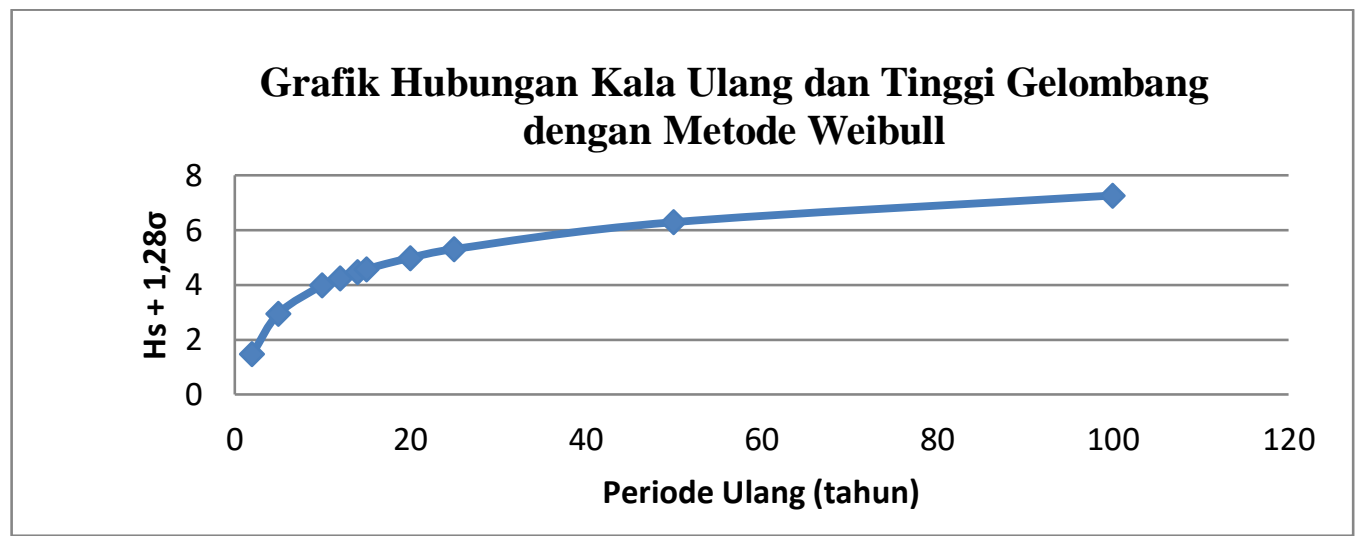

Gambar 12. Grafik Hubungan (hsr+1,28 or) dan Periode Ulang Tertentu dengan Metode Weibull.

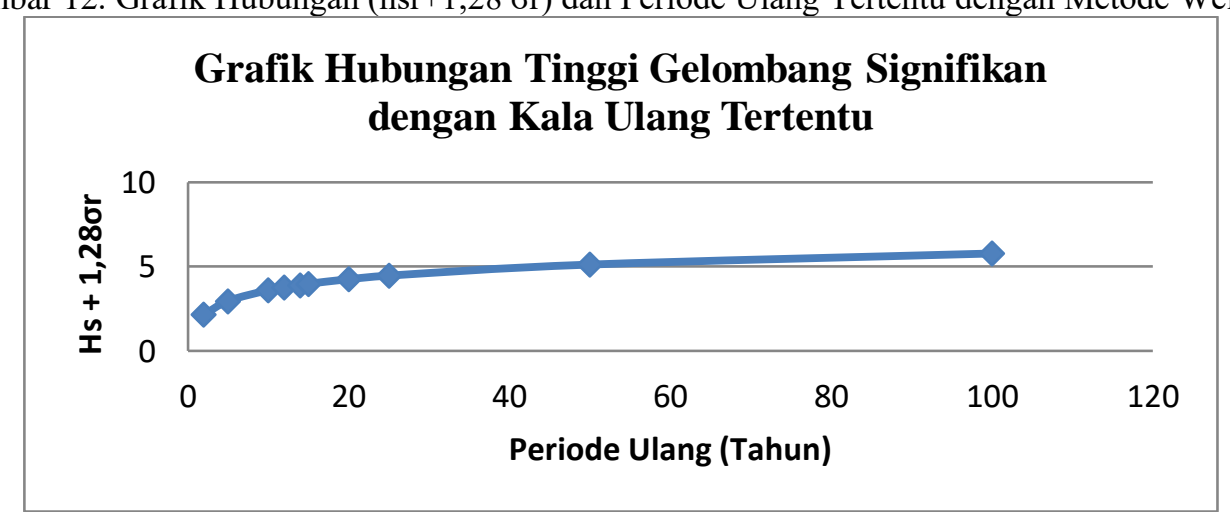

Gambar 13. Grafik Gelombang signifian dengan kala ulang tertentu dengan metode Fisher Tippet Type I Dari kedua grafik di atas terlihat nilai ekstrim yang terjadi pada kala ulang 14 tahun sebesar 3,9201 m untuk hasil perhitungan dengan menggunakan metode Fisher Tippet Tipe I dan 4,480 m dengan menggunakan Metode Weibull. Sedangkan pada pengukuran data angin yang di transformasikan menjadi data gelombang, didapatkan nilai tertimggi sebesar 3,76 $\mathrm{m}$. Sehingga dalam peramalan gelombang ekstrim dalam penelitian ini metode Fisher Tippet Tipe I lebih memenuhi. 


\section{SIMPULAN}

Berdasarkan hasil penelitian ini didapatkan beberapa kesimpulan sebagai berikut :

1. Berdasarkan tabel dan diagram mawar angin tahun 1989-1993 didapatkan arah angin dominan sebesar 9,284\% dari arah tenggara, dan kecepatan angin dominan terjadi kecepatan 4-6 knot dengan distribusi kecepatan angin dominan sebesar $24,299 \%$. Pada hasil mawar gelombang didapatkan arah gelombang dominan dari arah utara dengan persentase $48,062 \%$ dan kecepatan angin pembangkit gelombang dominan terjadi pada kecepatan 7-10 knot yaitu sebesar $12,845 \%$. Ketidaksesuaian itu terjadi akibat dari jarak pengukuran angin dan gelombang yang berjarak $99 \mathrm{~km}$.

2. Pengklasifikasian kecepatan dan arah yang dilakukan terhadap angin pada tahun 1989-1993 dan 2007-2011 menunjukkan perubahan kecepatan angin yang terjadi pada kecepatan 4-6 knot. Pada tahun 2007-2011 mengalami distribusi sebaran yang lebih kecil dibandingkan tahun1989-1993. Pada kecepatan 1-3 knot dan 7-10 knot terjadi kenaikan sebaran distribusi berdasarkan kecepatan. Hal ini menunjukkan adanya efek dari climate change yang ditandai dengan penurunan distribusi sebaran tersebut.

3. Berdasarkan Grafik Hubungan Tinggi Gelombang Signifikan Pertahun, terdapat kenaikan gelombang dari tahun 1989 hingga tahun 1993. Hal ini menunjukkan adanya efek dari perubahan iklim yang terjadi selama rentang tahun tersebut.

4. Grafik hubungan antara gelombang terukur dan waktu pada lokasi Pelabuhan Panjang memberikan hasil yang tidak jauh berbeda. Hal itu menunjukkan bahwa gelombang yang terjadi di Pelabuhan Panjang akan mendekati dengan gelombang yang terjadi di lokasi pengukuran gelombang.

5. Peramalan gelombang ekstrim dengan menggunakan Metode Fisher Tippett Tipe I memberikan hasil yang mendekati dengan peramalan gelombang selama 14 tahun. Data angin yang diolah menjadi data gelombang terhitung sebesar 3,76 m dibandingkan dengan hasil peramalan gelombang dengan metode Fisher Tippet Type I sebesar 3,9201.

\section{REFERENSI/DAFTAR PUSTAKA}

Departement Of The Army (Waterways Experiment Station Corps Of Engineers COASTAL ENGINEER RESEARCH CENTER). 1984. Shore Protection Manual 1984 (Volume 1). The Superintendent Of Documents, U.S. Goverment Printing Service Washington D.C. Washington D.C. 337 hlm.

Food and Agriculture Organization of The United Nations (FAO). Sea Water Intrusion In Coastal Aquifer Guidelines For Study, Monitoring, and Control. 1997. 152 hlm.

Jokowinarno, Dwi. 2007. Penentuan Elevasi Permukaan Lahan Reklamasi di Teluk Lampung. Lampung : $9 \mathrm{hlm}$.

Kramadibrata, Soedjono. 2002. Perencanaan Pelabuhan. Institut Teknologi Bandung. Bandung : $471 \mathrm{hlm}$. Triatmodjo, Bambang. 1986. Pelabuhan. Beta Offset. Yogyakarta. 299 hlm.

Triatmodjo, Bambang. 1999. Teknik Pantai. Beta Offset. Yogyakarta. 397 hlm.

\section{BIOGRAFI PENULIS}

\begin{tabular}{|l|l|}
\hline & $\begin{array}{l}\text { Penulis dilahirkan di Metro pada tanggal 22 Desember 1988. Merupakan anak ketiga } \\
\text { dari lima bersaudara dari keluarga Bapak Sudarsono dan Ibu Sri Tatik }\end{array}$ \\
Handayani.Jenjang pendidikan penulis pada program Sarjana pada jurusan teknik Sipil \\
di universitas negeri di indonesia. Penulis terdaftar sebagai mahasiswa Fakultas Teknik, \\
Jurusan Teknik Sipil, Universitas Lampung dan S2 Teknik Pengelolaan Bencana Alam \\
di Universitas Gadjah Mada. Selama menjadi mahasiswa penulis aktif di organisasi \\
kemahasiswaan. Setelah lulus dari program sarjana Unila, penulis berkecimpung dalam \\
dunia pekerjaan yaitu pada CV. Karya Dinamis, dilanjutkan dengan menjadi staff teknik \\
pada Balai Besar Wilayah Sungai Bengawan Solo dan terkahir menjadi seorang pengajar \\
pada Universitas Teknokrat Indonesia.
\end{tabular}

